\title{
Effect of feed-related farm characteristics on relative values of genetic traits in dairy cows to reduce greenhouse gas emissions along the chain
}

\author{
C. E. Van Middelaar, ${ }^{* 1}$ P. B. M. Berentsen,† J. Dijkstra,† J. A. M. Van Arendonk,§ and I. J. M. De Boer* \\ *Animal Production Systems group, Wageningen University, PO Box 338, 6700 AH Wageningen, the Netherlands \\ †Business Economics group, Wageningen University, PO Box 8130, 6700 EW Wageningen, the Netherlands \\ $\ddagger$ Animal Nutrition group, Wageningen University, PO Box 338, 6700 AH Wageningen, the Netherlands \\ §Animal Breeding and Genomics Centre, Wageningen University, PO Box 338, $6700 \mathrm{AH}$ Wageningen, the Netherlands
}

\begin{abstract}
Breeding has the potential to reduce greenhouse gas (GHG) emissions from dairy farming. Evaluating the effect of a 1-unit change (i.e., 1 genetic standard deviation improvement) in genetic traits on GHG emissions along the chain provides insight into the relative importance of genetic traits to reduce GHG emissions. Relative GHG values of genetic traits, however, might depend on feed-related farm characteristics. The objective of this study was to evaluate the effect of feed-related farm characteristics on GHG values by comparing the values of milk yield and longevity for an efficient farm and a less efficient farm. The less efficient farm did not apply precision feeding and had lower feed production per hectare than the efficient farm. Greenhouse gas values of milk yield and longevity were calculated by using a whole-farm model and 2 different optimization methods. Method 1 optimized farm management before and after a change in genetic trait by maximizing labor income; the effect on GHG emissions (i.e., from production of farm inputs up to the farm gate) was considered a side effect. Method 2 optimized farm management after a change in genetic trait by minimizing GHG emissions per kilogram of milk while maintaining labor income and milk production at least at the level before the change in trait; the effect on labor income was considered a side effect. Based on maximizing labor income (method 1), GHG values of milk yield and longevity were, respectively, 279 and $143 \mathrm{~kg}$ of $\mathrm{CO}_{2}$ equivalents $\left(\mathrm{CO}_{2} \mathrm{e}\right) /$ unit change per cow per year on the less efficient farm, and 247 and $210 \mathrm{~kg}$ of $\mathrm{CO}_{2} \mathrm{e} /$ unit change per cow per year on the efficient farm. Based on minimizing GHG emissions (method 2), GHG values of milk yield and longevity were, respectively, 538 and $563 \mathrm{~kg}$ of $\mathrm{CO}_{2} \mathrm{e} /$ unit change per cow per year on the less efficient farm, and 453
\end{abstract}

Received May 1, 2014.

Accepted March 14, 2015.

${ }^{1}$ Corresponding author: Corina.vanMiddelaar@wur.nl and $441 \mathrm{~kg}$ of $\mathrm{CO}_{2} \mathrm{e} /$ unit change per cow per year on the efficient farm. Sensitivity analysis showed that, for both methods, the absolute effect of a change in genetic trait depends on model inputs, including prices and emission factors. Substantial changes in relative importance between traits due to a change in model inputs occurred only in case of maximizing labor income. We concluded that assumptions regarding feed-related farm characteristics affect the absolute level of GHG values, as well as the relative importance of traits to reduce emissions when using a method based on maximizing labor income. This is because optimizing farm management based on maximizing labor income does not give any incentive for lowering GHG emissions. When using a method based on minimizing GHG emissions, feedrelated farm characteristics affected the absolute level of the GHG values, but the relative importance of the traits scarcely changed: at each level of efficiency, milk yield and longevity were equally important.

Key words: breeding, milk yield, longevity, economic value

\section{INTRODUCTION}

Dairy cattle breeding has the potential to reduce greenhouse gas (GHG) emissions from dairy farming (e.g., Hayes et al., 2013). Breeding for increased animal productivity, for example, reduces the number of animals needed to produce the same amount of product and is seen as an important strategy to reduce GHG emissions (Hristov et al., 2013). In contrast to most other types of management strategies, such as dietary changes, breeding is a long-term strategy, with permanent and cumulative effects. This implies that good planning is essential when deciding on a breeding strategy.

Most studies that have explored breeding strategies to reduce GHG emissions focused on reducing the emissions of enteric $\mathrm{CH}_{4}$ (Bell et al., 2010; De Haas et al., 2011; Hansen Axelsson et al., 2013). Genetic improvement, however, can affect the whole farm, including the diet of dairy cows and on-farm feed production (Bell et 
al., 2010; Wall et al., 2010). As a result, not only enteric $\mathrm{CH}_{4}$ but also other GHG emissions related to characteristics of cows and activities on the dairy farm might change. In addition, a strategy can affect the type and amount of purchased products, such as feed and fertilizers. Hence, GHG emissions related to production of farm inputs might change as well. Evaluating the effect of a genetic improvement, therefore, requires an integrated approach that accounts for changes in farm management and includes all GHG emissions along the chain; that is, from production of farm inputs up to the farm gate (Wall et al., 2010; Van Middelaar et al., 2013a, 2014).

Evaluating the effect of a 1-unit change in genetic traits on GHG emissions along the chain (i.e., from production of farm inputs up to the farm gate) provides insight into the potential effect of individual traits to reduce GHG emissions (Van Middelaar et al., 2014). Such "GHG values" can be used to implement environmental performance of traits in breeding programs (Wall et al., 2010). Van Middelaar et al. (2014) examined 2 methods to calculate GHG values of genetic traits by using a whole-farm optimization model in combination with a life cycle approach (i.e., including all GHG emissions up to the farm gate). The first method optimized farm management before and after a change in genetic trait by maximizing labor income; the effect on GHG emissions was considered a side effect. The second method optimized farm management after a change in genetic merit by minimizing GHG emissions per kilogram of milk, while maintaining labor income and milk production at least at the level before the change in trait. The effect of methods was illustrated for an improvement of 1 genetic standard deviation in milk yield and in longevity. It was shown that GHG values of both traits were about twice as high when the focus was on minimizing GHG emissions than when the focus was on maximizing labor income. In addition, GHG values of milk yield were larger than GHG values of longevity, especially when focus was on maximizing labor income.

The GHG values calculated by Van Middelaar et al. (2014) applied to one typical dairy farm in 2020, with high efficiency concerning feed utilization and feed production at farm level. High efficiency in feed utilization was obtained by ignoring safety margins for true protein digested in the small intestine (DVE) and for rumen degradable protein balance (RDPB). Such an increase in efficiency might be reached by precision feeding. High efficiency in on-farm feed production was obtained by increasing grass and maize yields per hectare based on historical data analysis to estimate yields for 2020. Several studies have shown, however, that the environmental impact of milk production varies between farms, and that this variation is often feed-related (Thomassen et al., 2009; Meul et al., 2014). Examples of feed-related farm characteristics causing variation in GHG emissions are type and amount of feed used per cow, level of crop yield per hectare, and level of nitrogen application for on-farm roughage production (Thomassen et al., 2009; Meul et al., 2014). It is unclear how GHG values of genetic traits depend on feed-related farm characteristics (i.e., no precision feeding, lower yield per hectare).

The objective of this study was to explore the robustness of GHG values to assumptions on feed-related farm characteristics. The GHG values of milk yield and longevity were calculated for a less efficient farm and compared with those calculated for an efficient farm by Van Middelaar et al. (2014). The less efficient farm does not apply precision feeding and has a lower grass and maize yield per hectare than the efficient farm.

\section{MATERIALS AND METHODS}

Methods used to calculate GHG values of milk yield and longevity are described in detail in Van Middelaar et al. (2014). The following paragraphs include a short description of the most important aspects of the model and a description of the analysis to determine GHG values. Differences between the efficient and less efficient farm are explained.

The aggregate genotype for our analysis consisted of milk yield and longevity; genetic variation in other traits was ignored. The relative GHG value of a genetic trait represents the effect of a 1-unit change on GHG emissions at the chain level while keeping the other trait constant. The chain level included all processes related to milk production from the production of raw materials to produce farm inputs (e.g., feed and fertilizers) until the moment the milk leaves the farm gate. Results (income and GHG emissions) for the optimized farm before and after 1 standard deviation improvement of milk yield (longevity) were determined using a dairy farm linear programming (LP) model. Two methods were used for optimization. Method 1 optimized farm management by maximizing labor income, while the effect on GHG emissions was considered a side effect. This method is similar to that used to calculate economic values. Economic values express the change in economic efficiency of a farming system that result from genetic improvement of individual traits and form the basis for current breeding goals in dairy farming (e.g., Groen, 1988; Hietala et al., 2014). Method 2 optimized farm management by minimizing GHG emissions per kilogram of milk while maintaining not only labor income but also milk production from the herd at least at the level before the change trait. This method, therefore, shows what could be achieved if breeding results 
were fully directed at reducing GHG emissions within the constraints set for income and milk production.

\section{Dairy Farm LP Model}

The dairy farm LP model is based on Berentsen and Giesen (1995) and adapted to 2020 to allow exploration of economic and environmental consequences of dairy cattle breeding. The model includes all relevant activities and constraints that are common to Dutch dairy farms (e.g., on-farm feed production, purchase of feed products, animal production, and environmental policies). It distinguishes summer and winter periods regarding feeding and includes different dietary options (i.e., grass from grazing, grass silage, maize silage, and 3 types of concentrates that differ in protein levels). The maximum amount of fresh grass intake in summer was set to $12 \mathrm{~kg}$ of $\mathrm{DM} / \mathrm{cow}$ per day, based on ad libitum grass intake of cows grazing during daytime (Abrahamse et al., 2009). The central element of the model is an average dairy cow from the Holstein-Friesian breed, with a given milk production and calving in February. Feed requirements (energy and protein) and intake capacity of this average cow were determined using the bioeconomic model of Groen (1988). This model was used also to determine herd composition and yearly replacement rate, based on the average longevity of the cow. Adaptations of the LP model to future production circumstances include abolition of the milk quota, changes in prices of milk components and purchased feed products (Wageningen UR, 2013), increasing yield per hectare, and changes in environmental policies regarding application of fertilizers and manure on the farm. The environmental policies included an annual maximum supply of total mineral N/ha of $250 \mathrm{~kg}$ for grassland and $140 \mathrm{~kg}$ for maize land, and an annual maximum supply for $\mathrm{N} /$ ha from animal manure of $250 \mathrm{~kg}$ for farms with at least $70 \%$ grassland and 170 $\mathrm{kg}$ for farms with less than $70 \%$ grassland. Regarding phosphate $\left(\mathrm{P}_{2} \mathrm{O}_{5}\right)$, the annual maximum supply was 90 $\mathrm{kg}$ of $\mathrm{P}_{2} \mathrm{O}_{5} /$ ha for grassland and $60 \mathrm{~kg}$ of $\mathrm{P}_{2} \mathrm{O}_{5} /$ ha for arable land (based on soils with an average phosphate content). Constraints were set such that all manure produced on the farm had to be applied on the farm; that is, on grassland and maize land.

\section{Calculating GHG Emissions}

Life cycle assessment (LCA) was used to calculate emissions of $\mathrm{CO}_{2}, \mathrm{CH}_{4}$, and $\mathrm{N}_{2} \mathrm{O}$ from different stages along the production chain, from production of farm inputs until the moment that milk leaves the farm gate. Processes included were the extraction of raw materials to produce farm inputs (e.g., energy sources, fertilizers, feed), the manufacturing and distribution of these inputs, and all processes on the dairy farm involved in production of feed and milk. Emissions of $\mathrm{CO}_{2}, \mathrm{CH}_{4}$, and $\mathrm{N}_{2} \mathrm{O}$ were combined based on their equivalence factor in terms of $\mathrm{CO}_{2}$ equivalents $\left(\mathbf{C O}_{2} \mathbf{e} ; 100\right.$-yr time horizon): 1 for $\mathrm{CO}_{2}, 25$ for $\mathrm{CH}_{4}$, and 298 for $\mathrm{N}_{2} \mathrm{O}$ (Forster et al., 2007). Emissions were calculated per tonne of fat- and protein-corrected milk (FPCM); that is, milk corrected to a fat percentage of $4.0 \%$ and a protein content of 3.3\% (Product Board Animal Feed, 2008). After accumulating emissions, they were allocated to the output of milk and meat from culled calves and cows based on the prices (including value added tax; Wageningen UR, 2008) of these outputs (i.e., economic allocation). Economic allocation is most commonly used in LCA studies of livestock products (De Vries and De Boer, 2010).

\section{Setup of the Analysis}

The LP model was used to determine the farm plan of the farm in the technical and institutional setting of 2020 , and with a cow that has the same characteristics as an average Holstein Friesian cow in 2013. The farm area is 85 ha, which is the estimated size of an average Dutch dairy farm in 2020 (Rabobank, 2009). Traits of the average cow (milk yield, fat and protein contents of the milk, and longevity) were based on the CRV database (CRV, 2012) and are included in Table 1. Table 1 also includes information on feed requirements of the cow (Groen, 1988). Optimization of farm management by maximizing labor income resulted in the reference scenario; that is, the scenario before genetic improvement.

To determine the effect of a 1-unit change in milk yield and longevity, each trait was increased by 1 genetic standard deviation while keeping the other traits constant. The genetic standard deviation for milk yield is $687 \mathrm{~kg} /$ cow per year (standard deviation applies to milk yield of a mature cow), and for longevity $270 \mathrm{~d}$ (CRV, 2012). Longevity is defined as the actual age in days when the cow leaves the farm. Using the model of Groen (1988), the effects of this change on average production, feed requirements, herd composition, and replacement rate were determined (Table 1).

The new data on milk yield, feed requirements, and replacement rate for the 2 scenarios (i.e., increased milk yield and increased longevity) were incorporated in the model, and then the impact on GHG emissions was determined by 1 of the 2 objectives: maximizing labor income (method 1) or minimizing GHG emissions per kilogram of milk (method 2). 


\section{Differences Between the Efficient Farm and the Less Efficient Farm}

Van Middelaar et al. (2014) made 2 important assumptions regarding feed-related farm characteristics. First, grass and maize yields for 2020 were based on current yields plus an average annual yield increase according to historical data analysis (Berentsen et al., 1996; Rijk et al., 2013). Grass yield in 2020 was assumed to be 72.2 GJ of $\mathrm{NE}_{\mathrm{L}} /$ ha per year (based on a fertilization level of $200 \mathrm{~kg}$ of $\mathrm{N} / \mathrm{ha}$ ) and maize yield of 108.2 GJ of $\mathrm{NE}_{\mathrm{L}} /$ ha per year. Second, safety margins for DVE and for RDPB were eliminated.

To explore the sensitivity of GHG values of genetic traits regarding these feed-related farm characteristics, 2 changes were made that lowered the efficiency of the farm compared with that of the efficient farm described by Van Middelaar et al. (2014): grass and maize yields per hectare per year were set at $95 \%$ of the yields in the efficient farm, and safety margins for DVE and RDPB were set at 100 and $200 \mathrm{~g} / \mathrm{cow}$ per day, respectively, compared with zero in the efficient farm. Safety margins used on the less efficient farm correspond with those used in studies focusing on current systems (Van Middelaar et al., 2013a). Crop production and precision feeding were considered the most relevant farm characteristics related to feed that influence farm efficiency.

\section{Deriving Economic and GHG Values}

Economic values represent the change in labor income from the farm, expressed per cow per year as a result of an increase of 1 genetic standard deviation in a trait while keeping the other traits constant. Change in labor income was calculated as labor income after change in genetic trait minus labor income before change in genetic trait. Subsequently, this change was divided by the number of dairy cows present before the change in genetic trait (Groen, 1989).

The GHG values represent the change in GHG emissions along the chain, expressed per cow per year as a result of an increase of 1 genetic standard deviation in a trait while keeping the other traits constant. Changes in GHG emissions were calculated as kilograms of $\mathrm{CO}_{2} \mathrm{e}$ per tonne of FPCM before a change in genetic trait minus kilograms of $\mathrm{CO}_{2} \mathrm{e}$ per tonne of FPCM after a change in genetic trait. Subsequently, this change was multiplied by FPCM production per cow per year (tonnes) before the change in genetic trait.

\section{Sensitivity Analysis}

To verify results and quantify the effect of assumptions regarding prices and emission factors on GHG values, we performed a sensitivity analysis. Prices of purchased feed products (including concentrates and maize silage), and emissions related to production of concentrates and enteric fermentation were considered important parameters; that is, they contain uncertainty, show temporal and spatial variation, and can influence results (enteric fermentation and feed production are environmental hotspots in dairy farming with regard to GHG emissions). To determine to which parameter GHG values were most sensitive, both prices and emission factors were changed by $20 \%$ for both the reference scenario and the scenarios with higher milk yield and higher longevity, respectively. In addition, a change in feed product prices provides insight into the effect of price fluctuation, whereas a change in emission factors provides insight into a change in concentrate composition or production circumstances (concentrate production), and into the effect of variation between animals (enteric fermentation). This $20 \%$ change is in line with the uncertainty range of the Intergovernmental Panel on Climate Change (IPCC) Tier 2 approach to calculate enteric $\mathrm{CH}_{4}$ emissions (IPCC, 2006) and with differences in emission factors within feed ingredients found in literature (e.g., Nguyen et al., 2012; Van Middelaar et al., 2013b; Vellinga et al., 2013). The difference between the highest and the lowest price of composed concentrates observed over the last $10 \mathrm{yr}$ is about 25\% (Wageningen UR, 2001-2013).

\section{RESULTS AND DISCUSSION}

Below we discuss results of the less efficient farm and compare these to results of the efficient farm, which are included in Tables A1 and A2 in the Appendix. In all situations, diets of young stock consisted of milk replacer and concentrates in the first months, followed by grass and concentrates during the summer period and maize silage and concentrates during the winter period.

\section{Maximizing Labor Income (Method 1)}

Diets and Farm Plan. Table 2 shows the diets, farm plan, and farm outputs of the reference scenario and the scenarios in which milk yield or longevity was increased by 1 genetic standard deviation.

For the reference scenario in summer, the maximum amount of fresh grass was fed, which is the cheapest way of feeding. Maize silage and medium protein concentrates were added to meet requirements for energy and RDPB. In winter, the diet contained $4.9 \mathrm{~kg} \mathrm{DM}$ of grass silage per cow per day, based on the amount of grass remaining after grazing during summer. Maize silage and medium protein concentrates were added to meet requirements for energy and RDPB. The refer- 
Table 1. Production traits and feed requirements per cow and yearly replacement rate of the dairy herd for the reference scenario and after increasing milk yield and longevity by 1 genetic standard deviation ${ }^{1}$

\begin{tabular}{|c|c|c|c|c|c|c|c|c|}
\hline \multirow[b]{2}{*}{ Item } & \multicolumn{4}{|c|}{ Production traits } & \multicolumn{3}{|c|}{ Feed requirements ${ }^{2}$} & \multirow[b]{2}{*}{$\begin{array}{l}\text { Replacement } \\
\text { rate (\%) }\end{array}$} \\
\hline & $\begin{array}{l}\text { Milk } \\
\text { yield } \\
(\mathrm{kg} / \mathrm{yr})\end{array}$ & Fat $(\%)$ & $\begin{array}{l}\text { Protein } \\
\quad(\%)\end{array}$ & $\begin{array}{l}\text { Longevity }^{3} \\
\text { (No. of days) }\end{array}$ & $\begin{array}{c}\text { Energy } \\
\text { (GJ of } \mathrm{NE}_{\mathrm{L}} / \mathrm{yr} \text { ) }\end{array}$ & $\begin{array}{c}\text { Protein } \\
(\mathrm{kg} \text { of DVE/yr) }\end{array}$ & $\begin{array}{l}\text { Intake } \\
\text { capacity } \\
(\mathrm{kg} / \mathrm{yr})\end{array}$ & \\
\hline Reference $^{4}$ & 8,758 & 4.32 & 3.51 & 2,150 & 44,553 & 545 & 6,009 & 27.0 \\
\hline Increased milk yield & 9,445 & 4.32 & 3.51 & 2,150 & 46,961 & 583 & 6,137 & 27.0 \\
\hline Increased longevity & $8,795^{5}$ & 4.31 & 3.51 & 2,420 & 44,712 & 547 & 6,037 & 22.5 \\
\hline
\end{tabular}

${ }^{1}$ Genetic standard deviation for milk yield is $687 \mathrm{~kg} / \mathrm{yr}$, and for longevity $270 \mathrm{~d}$ (CRV, 2012).

${ }^{2}$ The diet has to meet a minimum requirement for energy $\left(\mathrm{NE}_{\mathrm{L}}\right)$, a minimum requirement for true protein digested in the small intestine (DVE), and a minimum requirement for rumen degradable protein balance (RDPB, not included in the table, for all scenarios set to $0 \mathrm{~g} / \mathrm{d}$ ). In addition, a maximum for intake capacity is included ( $\mathrm{kg}$ of DM of the reference feed according to Jarrige, 1988).

${ }^{3}$ Longevity is defined as the actual age in days.

${ }^{4}$ The reference scenario is based on an average Holstein-Friesian dairy cow in 2013 (CRV, 2012).

${ }^{5}$ First-lactation yield was the same as in the reference scenario.

ence scenario had 145 dairy cows, 60.6 ha of grassland, and 24.4 ha of maize land. The number of cows reached the level where maize silage had to be purchased in case of a further increase. Division of the land between grass and maize production was determined by energy production per hectare and $\mathrm{P}_{2} \mathrm{O}_{5}$ application standards. Maize land had a higher energy production per hectare than grassland, but lower $\mathrm{P}_{2} \mathrm{O}_{5}$ application standards.

Table 2. Diets, farm plan, and farm outputs of the less efficient farm, for the reference scenario and after increasing milk yield and longevity by 1 genetic standard deviation, based on maximizing labor income

\begin{tabular}{|c|c|c|c|}
\hline Item & Reference & Milk yield & Longevity \\
\hline \multicolumn{4}{|l|}{ Diet ( $\mathrm{kg}$ of $\mathrm{DM} /$ cow per day) } \\
\hline \multicolumn{4}{|l|}{ Summer period } \\
\hline Grass silage, $225 \mathrm{~kg}$ of $\mathrm{N} / \mathrm{ha}$ & 12.0 & 12.0 & 12.0 \\
\hline Maize silage & 5.1 & 5.6 & 5.1 \\
\hline Concentrate, medium protein & 3.7 & 4.3 & 3.7 \\
\hline Diet restriction $^{1}$ & $\mathrm{E}, \mathrm{R}$ & $E, R$ & $E, R$ \\
\hline \multicolumn{4}{|l|}{ Winter period } \\
\hline Grass silage, $225 \mathrm{~kg}$ of N/ha & 4.9 & 7.2 & 4.9 \\
\hline Maize silage & 5.3 & 6.3 & 5.3 \\
\hline Concentrate, medium protein & 7.1 & 5.2 & 7.2 \\
\hline Diet restriction $^{1}$ & $\mathrm{E}, \mathrm{R}$ & $\mathrm{E}, \mathrm{R}, \mathrm{I}$ & $E, R$ \\
\hline \multicolumn{4}{|l|}{ Farm plan } \\
\hline Dairy cows (no.) & 145 & 147 & 150 \\
\hline Young stock ${ }^{2}(\mathrm{U})$ & 44 & 45 & 38 \\
\hline Grassland, $225 \mathrm{~kg}$ of N/ha (ha) & 60.6 & 68.0 & 60.7 \\
\hline Maize land (ha) & 24.4 & 17.0 & 24.3 \\
\hline \multicolumn{4}{|l|}{ Synthetic fertilizer } \\
\hline $\mathrm{kg}$ of $\mathrm{N} / \mathrm{ha}$ & 100 & 105 & 100 \\
\hline $\mathrm{kg}$ of $\mathrm{P}_{2} \mathrm{O}_{5} / \mathrm{ha}$ & - & - & - \\
\hline Purchased maize silage ( $\mathrm{t}$ of $\mathrm{DM}$ ) & - & 155 & - \\
\hline Purchased concentrate ( $\mathrm{t}$ of $\mathrm{DM}$ ) & 310 & 279 & 320 \\
\hline Manure application restriction ${ }^{3}$ & $\mathrm{P}$ & $\mathrm{P}$ & $\mathrm{P}$ \\
\hline \multicolumn{4}{|l|}{ Farm output } \\
\hline Milk ( $\mathrm{t}$ of $\left.\mathrm{FPCM}^{4}\right)$ & 1,336 & 1,459 & 1,380 \\
\hline Dairy cows (no.) & 39 & 39.7 & 33.7 \\
\hline Young stock, $>12 \mathrm{mo}$ (no.) & 3.4 & 3.5 & 2.9 \\
\hline Young stock, <12 mo (no.) & 1.8 & 1.8 & 1.5 \\
\hline Calves (no.) & 101 & 102.4 & 111.7 \\
\hline Labor income $(€)$ & 89,885 & 107,781 & 101,010 \\
\hline
\end{tabular}

${ }^{1}$ The diet can be restricted by $\mathrm{E}=$ energy requirements; $\mathrm{R}=$ rumen degradable protein balance; $\mathrm{T}=$ true protein digested in the small intestine; I = intake capacity.

${ }^{2}$ One unit includes 1 animal $<12$ mo and 0.96 animal $>12$ mo.

${ }^{3}$ The intensity of the farm is restricted by the possibility to apply manure. Manure application can be restricted by $\mathrm{tN}=$ total mineral $\mathrm{N} ; \mathrm{aN}=\mathrm{N}$ from animal manure; $\mathrm{P}=$ total $\mathrm{P}_{2} \mathrm{O}_{5}$.

${ }^{4} \mathrm{FPCM}=$ fat- and protein-corrected milk. 
The result was an area of grass and maize land that resulted in the highest number of cows (based on $\mathrm{P}_{2} \mathrm{O}_{5}$ application standards) without purchasing maize silage. In the reference scenario, total milk production at farm level was 1,336 t of FPCM/year; that is, $5.7 \mathrm{t}$ of $\mathrm{FPCM} /$ ha per year and labor income of $€ 89,885 / \mathrm{yr}$.

Increasing milk yield changed the diets and farm plan (Table 2). The number of cows increased from 145 to 147 , and the amount of maize land was decreased in favor of grassland. Diets were changed to meet the increased requirements for energy and protein per cow (Table 1) and because the area of grassland increased. In the reference scenario, reducing maize land in favor of grassland to allow for an increase in the number of cows was no longer beneficial when maize silage had to be purchased. After increasing milk yield, the revenues per cow increased, and reducing maize land in favor of grassland to increase the number of cows was beneficial in a situation where maize silage had to be purchased. The number of cows and area of grassland increased until the intake capacity of the cow limited the uptake of grass silage in winter. Total milk production at the farm level increased to 1,459 t of FPCM/yr and labor income to $€ 107,781$. This corresponds to an increase of $€ 123 /$ unit change per cow per year.

Increasing longevity slightly increased energy and protein requirements per cow (Table 1), explaining the increase in the amount of concentrates per cow per day during winter (this did not include the requirements and diets of young stock). The reduced replacement rate resulted in fewer young stock and lower manure production of the herd. The number of cows reached the level where maize silage had to be purchased. After increasing longevity, the number of cows on the farm was 150, total milk production 1,380 t of $\mathrm{FPCM} / \mathrm{yr}$, and labor income €101,010/yr. This corresponds to an increase of $€ 77 /$ unit change per cow per year.

Comparison of the reference scenarios of the less efficient and efficient farms (Appendix, Table A1) showed that the less efficient farm had fewer cows, a lower milk production per hectare, and higher production costs. The less efficient farms have fewer cows because of the inclusion of safety margins for RDPB and DVE, resulting in an increase in the amount of concentrates and an increase in the $\mathrm{P}$ content of manure (i.e., $\mathrm{P}_{2} \mathrm{O}_{5}$ application standards limit the number of cows). Because of the higher production costs, no maize silage was purchased on the less efficient farm, whereas it was purchased on the efficient farm. On the less efficient farm, diets contained more concentrates and less maize silage per cow per day than on the efficient farm. Labor income was $22 \%$ lower on the less efficient farm than on the efficient farm.
On both the less efficient and the efficient farms, increasing milk yield resulted in a situation where maize land was reduced in favor of grassland and (more) maize silage was purchased to facilitate an increase in number of cows. Increasing longevity also increased the number of cows, but on the less efficient farm, the increase stopped at the point where maize silage had to be purchased.

For the less efficient farm, economic values of milk yield and longevity were $€ 123$ and $€ 77$ per cow per year (i.e., method 1). For the efficient farm, these values were $€ 122$ and $€ 82$ per cow per year. The economic value of milk yield was similar on both farms, whereas the economic value of longevity was higher on the efficient farm than on the less efficient farm. In case of the less efficient farm, costs related to feeding dairy cows accounted for a larger part of the total costs. An increase in longevity is effective mainly because it reduces the number of young stock. For the less efficient farm, costs related to young stock determined a smaller part of the total costs, reducing the importance of longevity relative to milk yield compared with the efficient farm.

GHG Emissions. Table 3 shows GHG emissions for the reference scenario and changes in emissions after increasing milk yield and longevity by 1 genetic standard deviation. Results in Table 3 are based on maximizing labor income (method 1$)$.

For the less efficient farm, the following results apply. In the reference scenario, total GHG emissions per tonne of FPCM were $946 \mathrm{~kg}$ of $\mathrm{CO}_{2} \mathrm{e}$ without allocation, and $853 \mathrm{~kg}$ of $\mathrm{CO}_{2} \mathrm{e}$ based on economic allocation. Most important contributors were enteric fermentation (48\%), production of concentrates (18\%), manure (13\%), and on-farm roughage production (13\%).

Increasing milk yield reduced emissions per tonne of FPCM due to dilution of emissions related to maintenance and young stock over more kilograms of milk (i.e., fewer animals were needed to produce the same amount of milk). Furthermore, emissions changed because of changes in optimum farm management. After increasing milk yield, more roughage and less concentrates were fed per kilogram of milk compared with the reference scenario. Because production of concentrates results in higher emissions than production of roughage, emissions related to feed production decreased. In total, GHG emissions per tonne of FPCM decreased by $40 \mathrm{~kg}$ of $\mathrm{CO}_{2} \mathrm{e}$ using no allocation, and by $30 \mathrm{~kg}$ of $\mathrm{CO}_{2} \mathrm{e}$ using economic allocation. Based on economic allocation, the GHG value of milk yield was $279 \mathrm{~kg}$ of $\mathrm{CO}_{2} \mathrm{e}$ /unit change per cow per year.

Increasing longevity reduced emissions per tonne of FPCM mainly by reducing the number of young stock needed for replacement (i.e., contributing to emissions 
Table 3. Greenhouse gas emissions for the reference scenario and the effect of increasing milk yield and longevity by 1 genetic standard deviation (in $\mathrm{kg}$ of $\mathrm{CO}_{2}$ equivalents/t of fat- and protein-corrected milk) based on maximizing labor income

\begin{tabular}{|c|c|c|c|c|c|c|}
\hline \multirow[b]{2}{*}{ Item } & \multicolumn{2}{|c|}{ Reference } & \multicolumn{2}{|c|}{ Milk yield } & \multicolumn{2}{|c|}{ Longevity } \\
\hline & $\mathrm{L}^{1}$ & $\mathrm{H}^{1}$ & $\mathrm{~L}$ & $\mathrm{H}$ & $\mathrm{L}$ & $\mathrm{H}$ \\
\hline \multicolumn{7}{|l|}{ Animal emissions } \\
\hline Enteric $\mathrm{CH}_{4}$ emissions, dairy cows & 377 & 372 & -5 & -5 & 0 & 3 \\
\hline Enteric $\mathrm{CH}_{4}$ emissions, young stock & 73 & 73 & -5 & -5 & -12 & -12 \\
\hline Manure & 126 & 118 & -6 & -5 & -6 & -6 \\
\hline \multicolumn{7}{|l|}{ On-farm feed production } \\
\hline Grassland & 80 & 67 & 5 & 6 & -2 & 6 \\
\hline Maize land & 40 & 37 & -14 & -14 & -1 & -13 \\
\hline \multicolumn{7}{|l|}{ Production of farm inputs } \\
\hline Maize silage & 0 & 24 & 19 & 18 & 0 & 17 \\
\hline Concentrates, dairy cows & 164 & 110 & -30 & -27 & 1 & -23 \\
\hline Concentrates, young stock & 8 & 8 & -1 & -1 & -1 & -1 \\
\hline Synthetic fertilizer & 55 & 51 & -2 & -2 & -2 & -2 \\
\hline Other inputs & 23 & 23 & -1 & -1 & 0 & 0 \\
\hline Total emissions & 946 & 882 & -40 & -36 & -24 & -32 \\
\hline Economic allocation ${ }^{2}$ & 853 & 796 & -30 & -27 & -16 & -23 \\
\hline
\end{tabular}

from enteric fermentation, manure, and concentrate production). Furthermore, emissions changed because of changes in optimum farm management. In total, GHG emissions per tonne of FPCM reduced by $24 \mathrm{~kg}$ of $\mathrm{CO}_{2} \mathrm{e}$ using no allocation, and by $16 \mathrm{~kg}$ of $\mathrm{CO}_{2} \mathrm{e}$ using economic allocation. Based on economic allocation, the GHG value of longevity was $143 \mathrm{~kg}$ of $\mathrm{CO}_{2} \mathrm{e} / \mathrm{unit}$ change per cow per year.

Compared with the efficient farm, the less efficient farm resulted in higher GHG emissions per tonne of FPCM; that is, 853 compared with $796 \mathrm{~kg}$ of $\mathrm{CO}_{2} \mathrm{e} / \mathrm{t}$ of FPCM (reference scenarios). Emissions from the production of purchased feed products, from on-farm feed production, and from enteric fermentation and manure management were higher on the less efficient farm than on the efficient farm. Results show that increasing farm efficiency via precision feeding and increasing roughage production per hectare is an effective way to reduce GHG emissions from milk production.

Effects of increasing milk yield on GHG emissions on the less efficient farm were largely similar to effects on the efficient farm: on the less efficient farm, emissions decreased by $3.5 \%$ and on the efficient farm by $3.4 \%$. Effects of increasing longevity on GHG emissions on the less efficient farm were less pronounced than on the efficient farm; on the less efficient farm, emissions reduced by $1.9 \%$, whereas on the efficient farm, emissions reduced by $2.9 \%$.

For the less efficient farm, GHG values of milk yield and longevity were 279 and $143 \mathrm{~kg}$ of $\mathrm{CO}_{2} \mathrm{e} /$ unit change per cow per year (Table 4 ). For the efficient farm, these values were 247 and $210 \mathrm{~kg}$ of $\mathrm{CO}_{2} \mathrm{e} /$ unit change per cow per year. Thus, with an increase in farm efficiency, the GHG value of milk yield decreased, whereas that of longevity increased. As a result, the importance of milk yield relative to longevity was greater on the less efficient farm than on the efficient farm. These results show that GHG values of milk yield and longevity depend on farm efficiency when maximizing labor income.

\section{Minimizing GHG Emissions per Kilogram of FPCM (Method 2)}

Diets and Farm Plan. Table 5 shows the diets, farm plan, and farm outputs of the reference scenario and the scenarios in which milk yield and longevity were increased and farm management was optimized to minimize GHG emissions per kilogram of milk (within the constraints set for labor income and milk production).

Table 4. Greenhouse gas (GHG) values of milk yield and longevity ( $\mathrm{kg}$ of $\mathrm{CO}_{2}$ equivalents/cow per year) for the less efficient and efficient farms based on maximizing labor income or minimizing GHG emissions $^{1}$

\begin{tabular}{lccc}
\hline Item & $\begin{array}{l}\text { Milk } \\
\text { yield }\end{array}$ & Longevity & Ratio \\
\hline Maximizing labor income & & & \\
$\quad$ Less efficient farm & 279 & 143 & 1.94 \\
$\quad$ Efficient farm & 247 & 210 & 1.18 \\
Minimizing GHG emissions & & & \\
$\quad$ Less efficient farm & 538 & 563 & 0.95 \\
Efficient farm & 453 & 441 & 1.03 \\
\hline
\end{tabular}

${ }^{1}$ Results are based on economic allocation. 
Table 5. Diets, farm plan, and farm outputs of the less efficient farm, for the reference scenario and after increasing milk yield and longevity by 1 genetic standard deviation, based on minimizing greenhouse gas emissions

\begin{tabular}{|c|c|c|c|}
\hline Item & Reference & Milk yield & Longevity \\
\hline \multicolumn{4}{|l|}{ Diet (kg of DM/cow per day) } \\
\hline \multicolumn{4}{|l|}{ Summer period } \\
\hline Grass, $225 \mathrm{~kg}$ of N/ha & 12.0 & 12.0 & 12.0 \\
\hline Maize silage & 5.1 & 7.7 & 7.0 \\
\hline Concentrate, medium protein & 3.7 & - & - \\
\hline Concentrate, high protein & - & 2.4 & 2.0 \\
\hline Diet restriction $^{1}$ & $\mathrm{E}, \mathrm{R}$ & $\mathrm{E}, \mathrm{R}$ & $\mathrm{E}, \mathrm{R}$ \\
\hline \multicolumn{4}{|l|}{ Winter period } \\
\hline Grass silage, $225 \mathrm{~kg}$ of $\mathrm{N} / \mathrm{ha}$ & 4.9 & 5.8 & 5.9 \\
\hline Maize silage & 5.3 & 8.3 & 8.6 \\
\hline Concentrate, medium protein & 7.1 & 1.8 & - \\
\hline Concentrate, high protein & - & 2.7 & 3.4 \\
\hline Diet restriction $^{1}$ & $\mathrm{E}, \mathrm{R}$ & $\mathrm{E}, \mathrm{R}, \mathrm{I}$ & $\mathrm{E}, \mathrm{R}, \mathrm{I}$ \\
\hline \multicolumn{4}{|l|}{ Farm plan } \\
\hline Dairy cows $(\mathrm{n})$ & 145 & 137 & 148 \\
\hline Young stock ${ }^{2}(\mathrm{U})$ & 44 & 42 & 38 \\
\hline Grassland, $225 \mathrm{~kg}$ of N/ha (ha) & 60.6 & 59.5 & 62.8 \\
\hline Maize land (ha) & 24.4 & 25.5 & 22.2 \\
\hline \multicolumn{4}{|l|}{ Synthetic fertilizer } \\
\hline $\mathrm{kg}$ of $\mathrm{N} / \mathrm{ha}$ & 100 & 101 & 102 \\
\hline $\mathrm{kg} \mathrm{P}_{2} \mathrm{O}_{5} / \mathrm{ha}$ & - & - & - \\
\hline Purchased maize silage ( $\mathrm{t}$ of $\mathrm{DM})$ & - & 109 & 169 \\
\hline Purchased concentrate ( $\mathrm{t}$ of $\mathrm{DM})$ & 310 & 192 & 163 \\
\hline Manure application restriction ${ }^{3}$ & $\mathrm{P}$ & $\mathrm{P}$ & $\mathrm{P}$ \\
\hline \multicolumn{4}{|l|}{ Farm output } \\
\hline Milk ( $\mathrm{t}$ of fat- and protein-corrected milk) & 1,336 & 1,360 & 1,362 \\
\hline Dairy cows (no.) & 39 & 37 & 33 \\
\hline Young stock, >12 mo (no.) & 3.4 & 3.2 & 2.9 \\
\hline Young stock, <12 mo (no.) & 1.8 & 1.7 & 1.5 \\
\hline Calves (no.) & 101 & 95 & 110 \\
\hline Labor income $(€)$ & 89,885 & 106,363 & 99,288 \\
\hline
\end{tabular}

The reference scenario is the same as that based on maximizing labor income. After increasing milk yield and subsequently minimizing GHG emissions per kilogram of milk, the number of cows decreased from 145 to 137 , and the amount of concentrates in the diets decreased. Labor income and total milk production were greater than in the reference scenario and consequently did not restrict changes in farm management. This implies that the optimal solution within the feasible solution space was determined by other constraints. The number of cows, and hence total milk production, was constrained by the amount of grass and grass silage produced (i.e., all grass was consumed) in combination with the maximum intake capacity of the cow. The area of grassland was 59.5 ha, which is exactly $70 \%$ of the total hectares available on farm; that is, the minimum area to allow application of maximal $250 \mathrm{~kg}$ of $\mathrm{N} /$ ha from animal manure instead of maximal $170 \mathrm{~kg}$ of $\mathrm{N} /$ ha. The number of cows and the amount of grass (silage) could have been reduced by reducing $\mathrm{N}$ fertil- ization on grassland. Due to a minimum requirement for total milk production (thus a minimum number of cows) and a minimum requirement for RDPB per cow, however, reducing $\mathrm{N}$ fertilization would have decreased grass production to a level that would have required an increase in the amount of concentrates per cow. Although concentrates result in a lower enteric $\mathrm{CH}_{4}$ emission than grass and grass silage, emissions during production are higher. Reducing the amount of concentrates in the diets, therefore, was more beneficial in terms of GHG emissions per kilogram of milk than reducing $\mathrm{N}$ fertilization on grassland. After increasing milk yield, and subsequently minimizing GHG emissions per kilogram of milk, total milk production at the farm level increased to 1,360 t of FPCM/yr and labor income to €106,363/yr.

After longevity was increased, the number of cows increased from 145 to 148, and the amount of concentrates in the diets decreased. Again, labor income and total milk production were not restricting. With total 
Table 6. Greenhouse gas (GHG) emissions for the reference scenario and the effect of increasing milk yield and longevity by 1 genetic standard deviation (in $\mathrm{kg}$ of $\mathrm{CO}_{2}$ equivalents/t of fat- and protein-corrected milk) based on minimizing GHG emissions ${ }^{1}$

\begin{tabular}{|c|c|c|c|c|c|c|}
\hline \multirow[b]{2}{*}{ Item } & \multicolumn{2}{|c|}{ Reference } & \multicolumn{2}{|c|}{ Milk yield } & \multicolumn{2}{|c|}{ Longevity } \\
\hline & $\mathrm{L}^{1}$ & $\mathrm{H}^{1}$ & $\mathrm{~L}$ & $\mathrm{H}$ & $\mathrm{L}$ & $\mathrm{H}$ \\
\hline \multicolumn{7}{|l|}{ Animal emissions } \\
\hline Enteric $\mathrm{CH}_{4}$ emissions, dairy cows & 377 & 372 & -8 & -2 & 3 & 11 \\
\hline Enteric $\mathrm{CH}_{4}$ emissions, young stock & 73 & 73 & -5 & -5 & -12 & -12 \\
\hline Manure & 126 & 118 & -5 & -5 & -5 & -5 \\
\hline \multicolumn{7}{|l|}{ On-farm feed production } \\
\hline Grassland & 80 & 67 & -2 & -1 & 3 & 8 \\
\hline Maize land & 40 & 37 & 0 & -5 & -5 & -20 \\
\hline \multicolumn{7}{|l|}{ Production of farm inputs } \\
\hline Maize silage & 0 & 24 & 14 & 15 & 22 & 32 \\
\hline Concentrates, dairy cows & 164 & 110 & -64 & -48 & -79 & -62 \\
\hline Concentrates, young stock & 8 & 8 & -1 & -1 & -1 & -1 \\
\hline Synthetic fertilizer & 55 & 51 & 0 & -8 & 0 & -8 \\
\hline Other inputs & 23 & 23 & 0 & 0 & 0 & 0 \\
\hline Total emissions & 946 & 882 & -71 & -60 & -74 & -59 \\
\hline Economic allocation $^{2}$ & 853 & 796 & -59 & -49 & -61 & -48 \\
\hline
\end{tabular}

milk production as a minimum constraint, the number of cows and the area of grassland increased until the maximum intake capacity of the cow was met. The area of grassland increased to facilitate the increase in the number of cows, because $\mathrm{P}_{2} \mathrm{O}_{5}$ application standards were limiting and application standards are higher for grassland than for maize land. The number of cows and area of grassland increased as long as the increase in grass and grass silage was fully consumed (i.e., intake capacity was restricting). This balance was reached at 148 cows. After increasing longevity, total milk production increased to 1,362 t of FPCM/yr and labor income to $€ 99,288 / \mathrm{yr}$.

Comparing results after increasing milk yield and longevity for the less efficient farm with results for the efficient farm (Appendix, Table A2) revealed 3 major differences. First, $\mathrm{N}$ fertilization on grassland was not reduced on the less efficient farm, whereas on the efficient farm it was. Because of higher RDPB requirements on the less efficient farm, reducing $\mathrm{N}$ fertilization on grassland, resulting in a lower RBPB content per kilogram of DM grass and grass silage, was not beneficial for reducing GHG emissions per kilogram of milk. Second, on both farms and for both traits, the amount of concentrates in the diets was reduced and the amount of roughage was increased. On the less efficient farm, however, the amount of concentrates per cow per day was larger than that on the efficient farm, because of the higher RDPB requirements. Third, on both farms and for both traits, the number of cows was increased until $\mathrm{P}_{2} \mathrm{O}_{5}$ application standards in combination with the maximum intake capacity of the cow were restricting. The final number of cows was lower on the less efficient farm than on the efficient farm. This was caused by a higher $\mathrm{P}$ content of manure on the less efficient farm because of higher RDPB requirements and a subsequent higher $\mathrm{P}$ content in the diet.

GHG Emissions. Table 6 shows GHG emissions of the reference scenario and changes in emissions after increasing milk yield and longevity. Farm management was optimized to minimizing GHG emissions per kilogram of milk.

After increasing milk yield per cow on the less efficient farm, emissions decreased due to dilution of emissions related to maintenance over more kilograms of milk, and due to changes in optimal farm management. Emissions from concentrate production decreased, whereas emissions from maize silage increased. Overall, emissions per tonne of FPCM decreased by $71 \mathrm{~kg}$ of $\mathrm{CO}_{2} \mathrm{e}$ using no allocation, and by $59 \mathrm{~kg}$ of $\mathrm{CO}_{2} \mathrm{e}$ using economic allocation. Based on economic allocation, the GHG value of milk yield was $538 \mathrm{~kg}$ of $\mathrm{CO}_{2} \mathrm{e} / \mathrm{unit}$ change per cow per year.

After increasing longevity, emissions related to young stock (enteric fermentation, manure, and concentrate production) decreased because of a reduction in young stock (i.e., reduced replacement rate). In addition, emissions decreased due to changes in optimal farm management. Overall, emissions per tonne of FPCM decreased by $74 \mathrm{~kg}$ of $\mathrm{CO}_{2} \mathrm{e}$ using no allocation, and by $61 \mathrm{~kg}$ of $\mathrm{CO}_{2} \mathrm{e}$ using economic allocation. Based on economic allocation, the GHG value of longevity is 563 $\mathrm{kg}$ of $\mathrm{CO}_{2} \mathrm{e} /$ unit change per cow per year. 
Differences between results of the less efficient and efficient farm can be explained mainly by the differences discussed earlier for diets and farm plan. After milk yield was increased, the reduction in emissions from concentrates production was greater on the less efficient farm than on the efficient farm, whereas the reduction in emissions related to on-farm roughage production was lower. The reduction in enteric $\mathrm{CH}_{4}$ emission was greater on the less efficient farm than on the efficient farm. This resulted from greater RDPB requirements, and hence, a greater amount of concentrates in the diets of the less efficient farm. This greater amount of concentrates resulted in lower enteric $\mathrm{CH}_{4}$ emissions after increasing milk yield, and, therefore, a higher emission reduction compared with the efficient farm. After increasing longevity, a similar pattern was shown. Additional differences in emissions related to on-farm feed production resulted from differences in the increase in grassland at the expense of maize land; that is, on the efficient farm, a larger part of maize land was changed into grassland.

For the less efficient farm, GHG values of milk yield and longevity were 538 and $563 \mathrm{~kg}$ of $\mathrm{CO}_{2} \mathrm{e} /$ unit change per cow per year (Table 4 ). For the efficient farm, these values were 453 and $441 \mathrm{~kg}$ of $\mathrm{CO}_{2} \mathrm{e} /$ unit change per cow per year. Thus, with a decrease in farm efficiency, GHG values of both milk yield and longevity increased. The ratios between GHG values of both traits, however, were comparable on both farms: on the less efficient farm and on the efficient farm, milk yield and longevity were about equally important for reducing GHG emissions.

\section{Sensitivity Analysis}

Figure 1 shows the effect of a $20 \%$ change in prices of purchased feed products on the GHG values of milk yield and longevity. The change in price changed the absolute level of the GHG values, as well as the relative importance of the traits in the case of maximizing labor income. In the case of minimizing GHG emissions, the absolute level of the values changed but the relative importance of the traits on each farm remained unchanged. The absolute values changed in both situations because of a change in the reference scenario, which was based on maximizing labor income. In all scenarios based on maximizing labor income, diets and farm plan changed with a change in price factors, which did not result in minimal GHG emissions. Results emphasize the sensitivity of GHG values for a change in prices of purchased feed products when using a method based on maximizing labor income.

Figure 2 shows the effect of a $20 \%$ change in emission factors of concentrates. An increase in emission fac- tors slightly increased GHG values when maximizing labor income, except for the value of longevity on the less efficient farm, because the effect of an increase in longevity on emissions from concentrate production was zero (Table 3). When minimizing GHG emissions, the absolute level of GHG values increased, whereas the relative importance of the traits changed little. In all scenarios, diets and farm plan remained unchanged with a change in emission factors.

A change in emission factors of enteric fermentation increased the GHG values of milk yield and longevity, but scarcely changed the relative importance of the traits (results not shown). In all scenarios, diets and
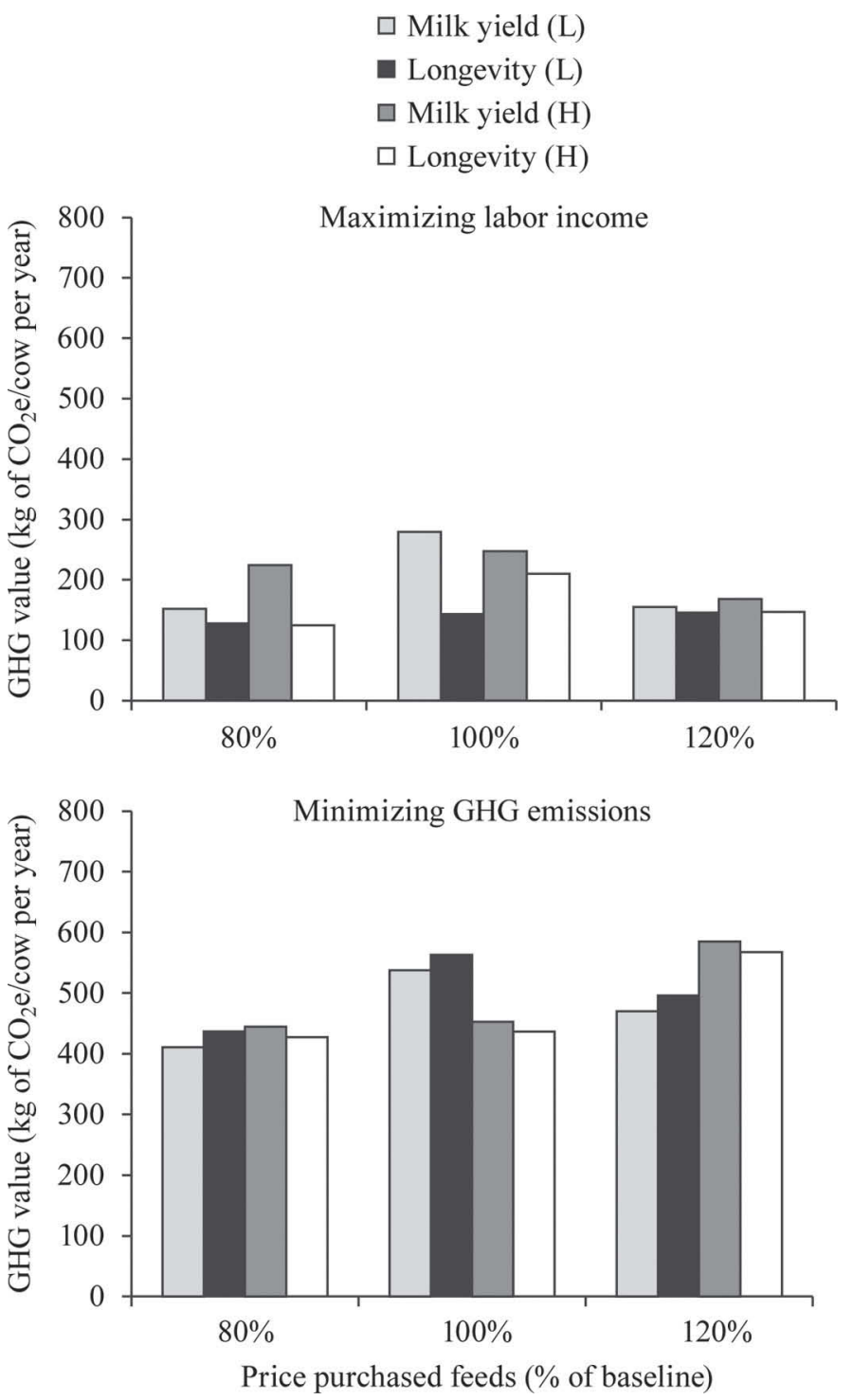

Figure 1. Effect of a $20 \%$ change in price of purchased feed products on greenhouse gas (GHG) values of milk yield and longevity on the less efficient $(\mathrm{L})$ and efficient $(\mathrm{H})$ farms based on maximizing labor income and minimizing GHG emissions. $\mathrm{CO}_{2} \mathrm{e}=\mathrm{CO}_{2}$ equivalents. 
farm plan remained unchanged with a change in emission factors.

Results of this sensitivity analysis confirmed that GHG values are less robust when using a method based on maximizing labor income than when using a method based on minimizing GHG emissions. Based on minimizing GHG emissions, changing prices and emission factors influenced the absolute level of the GHG values but not the relative importance of the traits.

\section{General Discussion}

The objective of this study was to explore the robustness of GHG values to assumptions on feed-related farm characteristics. Insight into this robustness is important, for example, when breeding organizations want to include GHG values into their breeding goal. When using a method based on maximizing labor income, the relative importance of traits to reduce emissions depends on assumptions regarding precision feeding, grass and maize silage yield per hectare, and on prices of purchased feed products. The GHG values derived from a method based on economic optimization and, therefore, they should be interpreted carefully when using them to make decisions in dairy cattle breeding. Despite the focus of this paper on feed-related farm characteristics, it should be noted that animal characteristics, such as milk yield and calving interval, might have important effects on the absolute and relative importance of traits to reduce GHG emissions as well.

Comparison between the less efficient and efficient farm suggest that the importance of milk yield relative to longevity increases with a decrease in farm efficiency. Results of the sensitivity analysis, however, show that this conclusion does not hold when prices of purchased feed products change. Based on the results of the sensitivity analysis, therefore, there is no structural difference between the efficient and less efficient farm regarding the potential of milk yield and longevity to reduce GHG emissions.

Attaching a negative economic value to GHG emissions would be a method to include GHG values into the breeding goal. In this study, we used 2 methods to determine GHG values, showing the maximum range of outcomes: by maximizing labor income, we created a situation where GHG emission costs do not influence results (emission costs are zero), whereas by minimizing GHG emissions, we created a situation where GHG emissions completely determine results. Because milk yield has a greater economic value than longevity, it has greater importance in the current breeding goal. In a situation where minimizing GHG emissions is the objective, milk yield and longevity are equally important. Thus, when a reduction in GHG emissions is

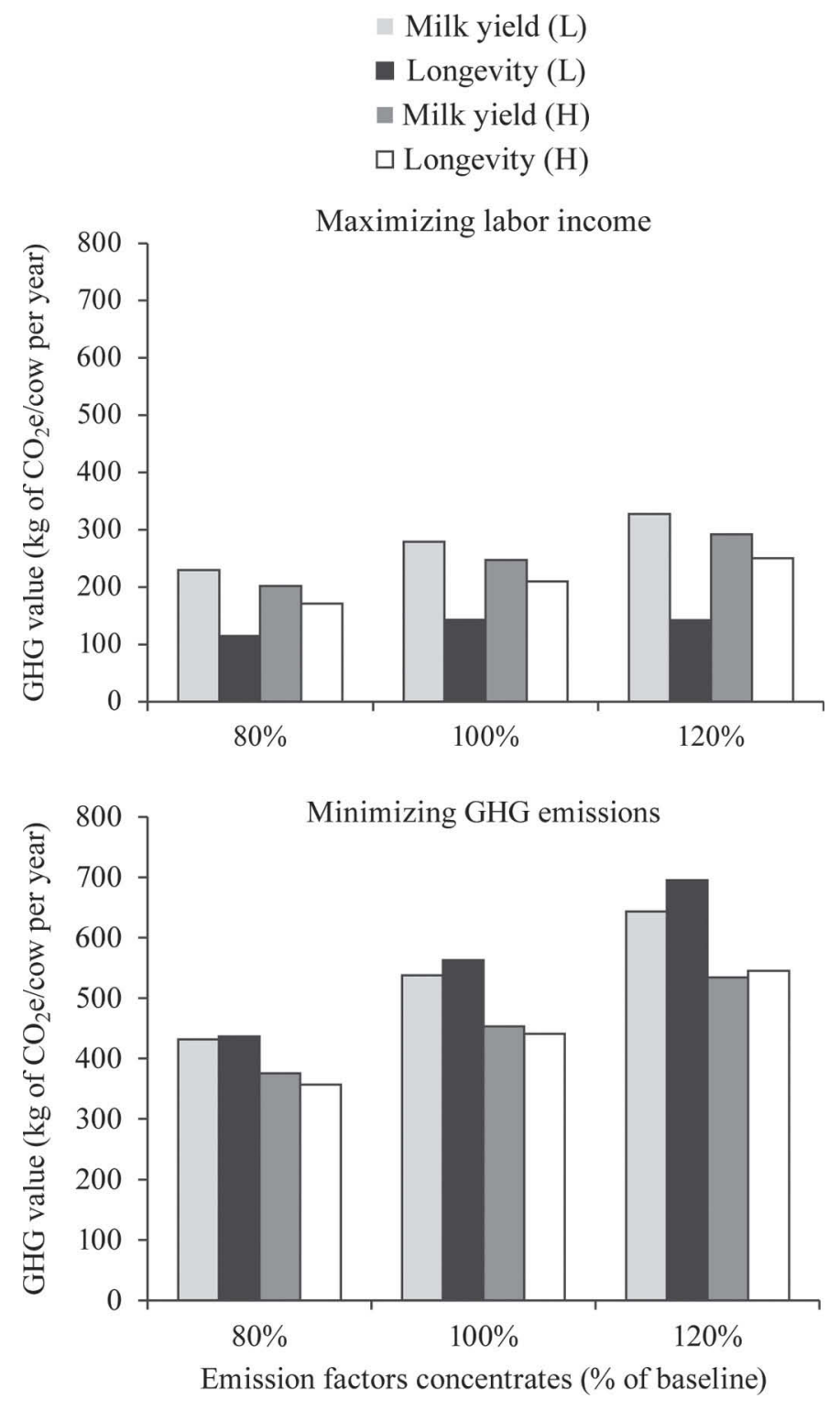

Figure 2. Effect of a $20 \%$ change in emission factors of concentrates on greenhouse gas (GHG) values of milk yield and longevity on the less efficient $(\mathrm{L})$ and efficient $(\mathrm{H})$ farms based on maximizing labor income and minimizing GHG emissions. $\mathrm{CO}_{2} \mathrm{e}=\mathrm{CO}_{2}$ equivalents.

going to be stimulated via subsidies or carbon taxes, milk yield remains more important than longevity, but the relative importance of milk yield over longevity will decrease with an increase in carbon price. Ảby et al. (2013) evaluated the effect of including GHG emission costs into economic values of traits for beef cattle and found no effect on the breeding goal ( $₫$ by et al., 2013). Those authors, however, only included GHG emissions related to enteric fermentation and manure management, and set 3 prices per tonne of $\mathrm{CO}_{2} \mathrm{e}: € 35, € 70$, and $€ 90$. An increase in price moderately affected the relative economic values of genetic traits ( $\AA$ by et al., 
2013). Conducting a similar study on genetic traits for dairy cattle could contribute to a better understanding of the effect of carbon taxes on future breeding goals.

This study used 2 methods to calculate GHG values of heritable traits, based on the same principle that is used to calculate economic values. Both methods used a whole-farm LP model, offering an objective method to simulate changes in farm management based on a guiding principle; that is, maximizing labor income or minimizing GHG emissions. In addition, both methods included an LCA approach to account for GHG emissions related to all processes on the farm and to production of farm inputs. This LCA approach prevents an overestimation of the GHG value of a trait based on substantial emission reduction at the animal or farm level, whereas the effect at chain level might be less positive. Combining a whole-farm LP model with LCA, therefore, offers a sound and objective method to evaluate the effect of genetic improvement on GHG emissions. Disadvantages of such a comprehensive method, however, are the number of input parameters required and the level of variability and uncertainty of these parameters. To improve calculations on GHG values, therefore, high quality data need to be collected for key processes; that is, animal and farm characteristics, emission factors, and prices. In addition, it is important to acknowledge that each farmer has his or her own management strategy and that breeding strategies to reduce GHG emissions can vary between farms.

Currently, genetic selection in dairy cattle is based on a breeding goal with a large number of traits. The traits in the breeding goal can be divided into production traits (e.g., milk yield, milk composition) and functional traits (e.g., longevity, reproduction, udder health). In this study, we considered only milk yield and longevity, where milk yield represents production traits and longevity the functional traits. The 2 traits provide important insights at this stage. As a next step toward implementation, GHG values of breeding goal traits other than milk yield and longevity need to be evaluated.

\section{CONCLUSIONS}

The effect of feed-related farm characteristics on GHG values of genetic traits was evaluated by comparing GHG values of milk yield and longevity for a less efficient farm with those for an efficient farm. Results suggest that the importance of milk yield relative to longevity increases with a decrease in farm efficiency when optimizing farm management based on maximizing labor income. This conclusion does not hold, however, when prices of purchased feed products change. The reason is that optimizing farm management based on maximizing labor income does not give any incentive for lowering GHG emissions. For that, GHG emissions would need to result in a cost (e.g., having a penalty on GHG emissions). When farm management was optimized based on minimizing GHG emissions, the absolute level of the values changed, but the importance of milk yield relative to longevity did not change; at each level of efficiency, both traits were equally important. Thus, the importance of milk yield relative to longevity does not depend on farm efficiency when minimizing GHG emissions. On both farms, GHG values based on minimizing GHG emissions were at least twice as great as those based on maximizing labor income.

\section{ACKNOWLEDGMENTS}

We thank CRV BV (Arnhem, the Netherlands), Agrifirm Group (Apeldoorn, the Netherlands), and the Ministry of Infrastructure and the Environment (Den Haag, the Netherlands) for financially supporting this research.

\section{REFERENCES}

Abrahamse, P. A., S. Tamminga, and J. Dijkstra. 2009. Effect of daily movement of dairy cattle to fresh grass in morning or afternoon on intake, grazing behaviour, rumen fermentation and milk production. J. Agric. Sci. (Camb.) 147:721-730.

Åby, B. A., L. Aass, E. Sehested, and O. Vangen. 2013. Effect of incorporating greenhouse gas emission costs into economic values of traits for intensive and extensive beef cattle breeds. Livest. Sci. 158:1-11.

Bell, M. J., E. Wall, G. Russell, C. Morgan, and G. Simm. 2010. Effect of breeding for milk yield, diet and management on enteric methane emissions from dairy cows. Anim. Prod. 50:817-826.

Berentsen, P. B. M., and G. W. J. Giesen. 1995. An environmentaleconomic model at farm level to analyse institutional and technical change in dairy farming. Agric. Syst. 49:153-175.

Berentsen, P. B. M., G. W. J. Giesen, and J. A. Renkema. 1996. Scenarios of technical and institutional change in Dutch dairy farming. Neth. J. Agric. Sci. 44:193-208.

CRV. 2012. International Dutch cattle improvement co-operative. Handboek CRV Hoofdstuk E-20 p. 2. Accessed May 14, 2013. https://www.crv4all.nl/downloads/e-hoofdstukken/e20.pdf.

De Haas, Y., J. J. Windig, M. P. L. Calus, J. Dijkstra, M. De Haan, A. Bannink, and R. F. Veerkamp. 2011. Genetic parameters for predicted methane production and potential for reducing enteric emissions through genomic selection. J. Dairy Sci. 94:6122-6134.

De Vries, M., and I. J. M. De Boer. 2010. Comparing environmental impacts for livestock products: A review of life cycle assessments. Livest. Sci. 128:1-11.

Forster, P., V. Ramaswamy, P. Artaxo, T. Berntsen, R. Betts, D. W. Fahey, J. Haywood, J. Lean, D. C. Lowe, G. Myhre, J. Nganga, R. Prinn, G. Raga, M. Schulz, and R. Van Dorland. 2007. Changes in Atmospheric Constituents and in Radiative Forcing. Climate Change 2007: The Physical Science Basis. Contribution of Working Group I to the Fourth Assessment Report of the Intergovernmental Panel on Climate Change. S. Solomon, D. Qin, M. Manning, Z. Chen, M. Marquis, K. B. Averyt, M. Tignor, and H. L. Miller, ed. Cambridge University Press, Cambridge, UK.

Groen, A. F. 1988. Derivation of economic values in cattle breeding: A model at farm level. Agric. Syst. 27:195-213.

Groen, A. F. 1989. Cattle breeding goals and production circumstances. PhD Thesis. Department of Farm Management and Depart- 
ment of Animal Breeding, Wageningen Agricultural University, Wageningen, the Netherlands.

Hansen Axelsson, H., W. F. Fikse, M. Kargo, A. C. Sørensen, K. Johansson, and L. Rydhmer. 2013. Genomic selection using indicator traits to reduce the environmental impact of milk production. J. Dairy Sci. 96:5306-5314.

Hayes, B. J., H. A. Lewin, and M. E. Goddard. 2013. The future of livestock breeding: Genomic selection for efficiency, reduced emissions intensity, and adaptation. Trends Genet. 29:206-214.

Hietala, P., M. Wolfová, J. Wolf, J. Kantanen, and J. Juga. 2014. Economic values of production and functional traits, including residual feed intake, in Finnish milk production. J. Dairy Sci. 97:1092-1106.

Hristov, A. N., J. Oh, J. L. Firkins, J. Dijkstra, E. Kebreab, G. Waghorn, H. P. S. Makkar, A. T. Adesogan, W. Yang, C. Lee, P. J. Gerber, B. Henderson, and J. M. Tricarico. 2013. Mitigation of methane and nitrous oxide emissions from animal operations: I. A review of enteric methane mitigation options. J. Anim. Sci. 91:5045-5069.

IPCC. 2006. Guidelines for National Greenhouse Gas Inventories. Volume 4: Agriculture, forestry and other land use. Intergovernmental Panel on Climate Change, prepared by the National Greenhouse Gas Inventories Program. H. S. Eggleston, L. Buendia, K. Miwa, T. Ngara, and K. Tanabe, ed. Institute for Global Environmental Strategies (IGES), Japan.

Jarrige, R. 1988. Alimentation des bovins, ovins et caprins. Institut National de la Recherche Agronomique, Paris, France.

Meul, M., C. E. Van Middelaar, I. J. M. De Boer, D. Fremaut, and G. Haesaert. 2014. Potential of life cycle assessment to support environmental decision making at commercial dairy farms. Agric. Syst. 131:105-115.

Nguyen, T. T. H., I. Bouvarel, P. Ponchant, and H. M. G. Van der Werf. 2012. Using environmental constraints to formulate low-impact poultry feeds. J. Clean. Prod. 28:215-222.

Product Board Animal Feed. 2008. Tabellenboek Veevoeding 2008. Productschap Diervoeder, CVB, Den Haag, the Netherlands.

Rabobank. 2009. Rapport Anders melken. De toekomst van de Nederlandse melkveehouderij. Report on prospects of the Dutch dairy sector for the year 2020. (in Dutch). Food and Agric. Team Rabobank, Centraal Twente, Hengelo, the Netherlands.
Rijk, H., M. K. Van Ittersum, and J. Withagen. 2013. Genetic progress in Dutch crop yields. Field Crops Res. 149:262-268.

Thomassen, M. A., M. A. Dolman, K. J. Van Calker, and I. J. M. De Boer. 2009. Relating life cycle assessment indicators to gross value added for Dutch dairy farms. Ecol. Econ. 68:2278-2284.

Van Middelaar, C. E., P. B. M. Berentsen, J. Dijkstra, and I. J. M. De Boer. 2013a. Evaluation of a feeding strategy to reduce greenhouse emissions from dairy farming: The level of analysis matters. Agric. Syst. 121:9-22.

Van Middelaar, C. E., P. B. M. Berentsen, J. Dijkstra, J. A. M. Van Arendonk, and I. J. M. De Boer. 2014. Methods to determine the relative value of genetic traits in dairy cows to reduce greenhouse gas emissions along the chain. J. Dairy Sci. 97:5191-5205.

Van Middelaar, C. E., C. Cederberg, T. V. Vellinga, H. M. G. Van Der Werf, and I. J. M. De Boer. 2013b. Exploring variability in methods and data sensitivity in carbon footprints of feed ingredients. Int. J. Life Cycle Assess. 18:768-782.

Vellinga, T. V., H. Blonk, M. Marinussen, W. J. Van Zeist, and I. J. M. De Boer. 2013. Methodology used in feedprint: a tool quantifying greenhouse gas emissions of feed production and utilization. Wageningen UR Livestock Research, the Netherlands. http://edepot.wur.nl/254098.

Wageningen UR. 2008. Quantitative Livestock Farming Information 2007-2008 (KWIN-V, Kwantitatieve Informative Veehouderij 2007-2008). Animal Sciences Group, Wageningen UR, Wageningen, the Netherlands.

Wageningen UR. 2013. Quantitative Livestock Farming Information 2012-2013 (KWIN-V, Kwantitatieve Informative Veehouderij 2012-2013). Livestock Research, Wageningen UR, Wageningen, the Netherlands.

Wageningen UR. 2001-2013. Quantitative Livestock Farming Information 2001-2013 (KWIN-V, Kwantitatieve Informative Veehouderij 2001-2013). Livestock Research, Wageningen UR, Wageningen, the Netherlands.

Wall, E., G. Simm, and D. Moran. 2010. Developing breeding schemes to assist mitigation of greenhouse gas emissions. Animal 4:366376 . 


\section{APPENDIX}

Tables A1 and A2 show results of the efficient farm (van Middelaar et al., 2014).

Table A1. Diets, farm plan, and farm outputs for the reference scenario and after increasing milk yield and longevity by 1 genetic standard deviation, based on maximizing labor income (reproduced with permission from van Middelaar et al., 2014)

\begin{tabular}{|c|c|c|c|}
\hline Item & Reference & Milk yield & Longevity \\
\hline \multicolumn{4}{|l|}{ Diet (kg of DM/cow per day) } \\
\hline \multicolumn{4}{|l|}{ Summer period } \\
\hline Grass silage, $225 \mathrm{~kg}$ of $\mathrm{N} / \mathrm{ha}$ & 12.0 & 12.0 & 12.0 \\
\hline Maize silage & 8.4 & 8.9 & 8.4 \\
\hline Concentrate, medium protein & 0.7 & 1.3 & 0.7 \\
\hline Diet restriction $^{1}$ & $\mathrm{E}, \mathrm{R}$ & $\mathrm{E}, \mathrm{R}$ & $\mathrm{E}, \mathrm{R}$ \\
\hline \multicolumn{4}{|l|}{ Winter period } \\
\hline Grass silage, $225 \mathrm{~kg}$ of $\mathrm{N} / \mathrm{ha}$ & 2.7 & 5.0 & 4.2 \\
\hline Maize silage & 8.0 & 8.9 & 8.4 \\
\hline Concentrate, medium protein & 6.5 & 4.6 & 5.0 \\
\hline Diet restriction $^{1}$ & $\mathrm{E}, \mathrm{R}$ & $\mathrm{E}, \mathrm{R}$ & $\mathrm{E}, \mathrm{R}$ \\
\hline \multicolumn{4}{|l|}{ Farm plan } \\
\hline Dairy cows (no.) & 168 & 171 & 182 \\
\hline Young $\operatorname{stock}^{2}(\mathrm{U})$ & 51 & 52 & 46 \\
\hline Grassland, $225 \mathrm{~kg}$ of N/ha (ha) & 59.5 & 67.9 & 67.4 \\
\hline Maize land (ha) & 25.5 & 17.1 & 17.6 \\
\hline \multicolumn{4}{|l|}{ Synthetic fertilizer } \\
\hline $\mathrm{kg}$ of $\mathrm{N} / \mathrm{ha}$ & 107 & 113 & 112 \\
\hline $\mathrm{kg}$ of $\mathrm{P}_{2} \mathrm{O}_{5} / \mathrm{ha}$ & - & - & - \\
\hline Purchased maize silage ( $\mathrm{t}$ of $\mathrm{DM}$ ) & 207 & 396 & 381 \\
\hline Purchased concentrate ( $\mathrm{t}$ of $\mathrm{DM})$ & 247 & 207 & 213 \\
\hline Manure application restriction $^{3}$ & $\mathrm{P}$ & $\mathrm{aN}, \mathrm{P}$ & $\mathrm{aN}, \mathrm{P}$ \\
\hline \multicolumn{4}{|l|}{ Farm output } \\
\hline Milk ( $\mathrm{t}$ of $\left.\mathrm{FPCM}^{4}\right)$ & 1,543 & 1,691 & 1,677 \\
\hline Dairy cows (no.) & 45.3 & 46.0 & 40.9 \\
\hline Young stock, >12 mo (no.) & 3.9 & 4.0 & 3.6 \\
\hline Young stock, <12 mo (no.) & 2.1 & 2.1 & 1.9 \\
\hline Calves (no.) & 116.8 & 118.6 & 135.7 \\
\hline Labor income $(€)$ & 115,050 & 135,477 & 128,765 \\
\hline
\end{tabular}

${ }^{1}$ The diet can be restricted by $\mathrm{E}=$ energy requirements; $\mathrm{R}=$ rumen degradable protein balance; $\mathrm{T}=$ true protein digested in the small intestine; I = intake capacity.

${ }^{2}$ One unit includes 1 animal $<12$ mo and 0.96 animal $>12$ mo.

${ }^{3}$ The intensity of the farm is restricted by the possibility of applying manure. Manure application can be restricted by $\mathrm{tN}=$ total mineral $\mathrm{N} ; \mathrm{aN}=\mathrm{N}$ from animal manure; $\mathrm{P}=\mathrm{P}_{2} \mathrm{O}_{5}$.

${ }^{4}$ Fat- and protein-corrected milk. 
Table A2. Diets, farm plan, and farm outputs for the reference scenario and after increasing milk yield and longevity by 1 genetic standard deviation, based on minimizing greenhouse gas emissions (reproduced with permission from van Middelaar et al., 2014)

\begin{tabular}{|c|c|c|c|}
\hline Item & Reference & Milk yield & Longevity \\
\hline \multicolumn{4}{|l|}{ Diet ( $\mathrm{kg}$ of $\mathrm{DM} /$ cow per day) } \\
\hline \multicolumn{4}{|l|}{ Summer period } \\
\hline Grass, $200 \mathrm{~kg}$ of N/ha & - & 11.7 & 12.0 \\
\hline Grass, $225 \mathrm{~kg}$ of $\mathrm{N} / \mathrm{ha}$ & 12.0 & - & - \\
\hline Maize silage & 8.4 & 9.3 & 8.4 \\
\hline Concentrate, medium protein & 0.7 & - & - \\
\hline Concentrate, high protein & - & 1.3 & 0.8 \\
\hline Diet restriction $^{1}$ & $\mathrm{E}, \mathrm{R}$ & $\mathrm{E}, \mathrm{R}, \mathrm{I}$ & $\mathrm{E}, \mathrm{R}$ \\
\hline \multicolumn{4}{|l|}{ Winter period } \\
\hline Grass silage, $200 \mathrm{~kg}$ of N/ha & - & 4.5 & 5.3 \\
\hline Grass silage, $225 \mathrm{~kg}$ of $\mathrm{N} / \mathrm{ha}$ & 2.7 & - & - \\
\hline Maize silage & 8.0 & 11.2 & 10.4 \\
\hline Concentrate, medium protein & 6.5 & - & - \\
\hline Concentrate, high protein & - & 2.9 & 2.3 \\
\hline Diet restriction $^{1}$ & $\mathrm{E}, \mathrm{R}$ & $\mathrm{E}, \mathrm{R}, \mathrm{I}$ & $\mathrm{E}, \mathrm{R}, \mathrm{I}$ \\
\hline \multicolumn{4}{|l|}{ Farm plan } \\
\hline Dairy cows (no.) & 168 & 157 & 178 \\
\hline Young stock ${ }^{2}(\mathrm{U})$ & 51 & 48 & 45 \\
\hline Grassland, $200 \mathrm{~kg}$ of N/ha (ha) & - & 62.4 & 72.5 \\
\hline Grassland, $225 \mathrm{~kg}$ of N/ha (ha) & 59.5 & - & - \\
\hline Maize land (ha) & 25.5 & 22.6 & 12.5 \\
\hline \multicolumn{4}{|l|}{ Synthetic fertilizer } \\
\hline $\mathrm{kg}$ of $\mathrm{N} / \mathrm{ha}$ & 107 & 92 & 95 \\
\hline $\mathrm{kg}$ of $\mathrm{P}_{2} \mathrm{O}_{5} / \mathrm{ha}$ & - & - & - \\
\hline Purchased maize silage ( $\mathrm{t}$ of $\mathrm{DM}$ ) & 207 & 338 & 512 \\
\hline Purchased concentrate ( $t$ of $\mathrm{DM}$ ) & 247 & 141 & 117 \\
\hline Manure application restriction ${ }^{3}$ & $\mathrm{P}$ & $\mathrm{P}$ & $\mathrm{P}$ \\
\hline \multicolumn{4}{|l|}{ Farm output } \\
\hline Milk ( $\mathrm{t}$ of $\left.\mathrm{FPCM}^{4}\right)$ & 1,543 & 1,558 & 1,640 \\
\hline Dairy cows (no.) & 45.3 & 42.4 & 40.0 \\
\hline Young stock, >12 mo (no.) & 3.9 & 3.7 & 3.5 \\
\hline Young stock, <12 mo (no.) & 2.1 & 1.9 & 1.8 \\
\hline Calves (no.) & 116.8 & 109.3 & 132.7 \\
\hline Labor income $(€)$ & 115,050 & 127,301 & 120,428 \\
\hline
\end{tabular}

${ }^{1}$ The diet can be restricted by $\mathrm{E}=$ energy requirements; $\mathrm{R}=$ rumen degradable protein balance; $\mathrm{T}=$ true protein digested in the small intestine; I = intake capacity.

${ }^{2}$ One unit includes 1 animal $<12$ mo and 0.96 animal $>12$ mo.

${ }^{3}$ The intensity of the farm is restricted by the possibility of applying manure. Manure application can be restricted by $\mathrm{tN}=$ total mineral $\mathrm{N} ; \mathrm{aN}=\mathrm{N}$ from animal manure; $\mathrm{P}=\mathrm{P}_{2} \mathrm{O}_{5}$.

${ }^{4}$ Fat- and protein-corrected milk. 